\title{
Biological control in the microbiome era: Challenges and opportunities
}

\author{
Massart Sébastien $^{a, *}$, Martinez-Medina Margarita $^{\mathrm{b}}$, Jijakli M. Haissam ${ }^{\mathrm{a}}$ \\ ${ }^{a}$ Laboratory of Integrated and Urban Phytopathology, University of Liège, Gembloux Agro-Bio Tech, Passage des déportés 2, 5030 Gembloux, Belgium \\ ${ }^{\mathrm{b}}$ Laboratory of Molecular Microbiology, Department of Biology, University of Girona, Girona, Spain
}

\section{H I G H L I G H T S}

- The plant microbiota has been neglected in biocontrol research.

- New sequencing technologies allow the study of microbiota and its role in biocontrol.

- Innovative biocontrol methods against plant pathogens will emerge.
G R A P H I C A L A B S T R A C T

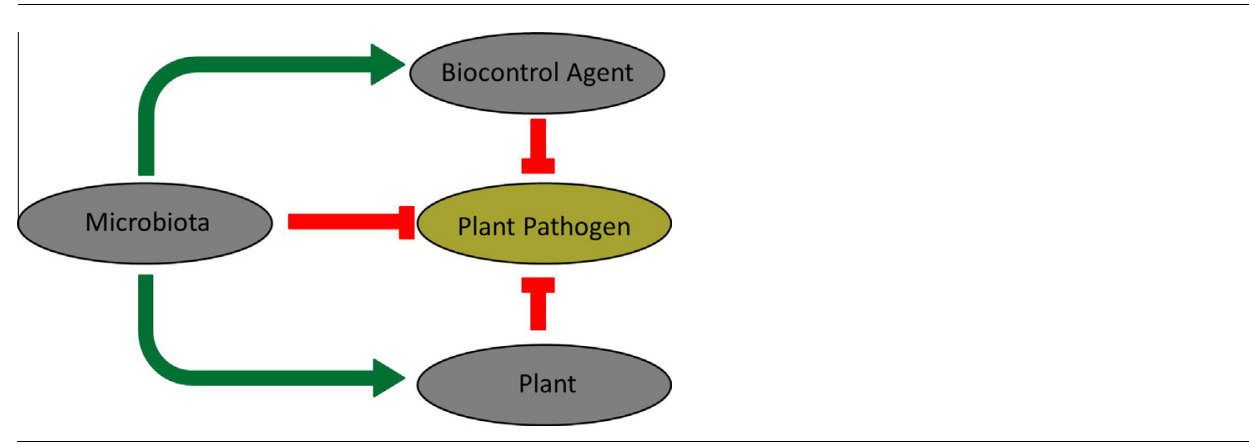

\section{A R T I C L E I N F O}

\section{Article history:}

Received 21 November 2014

Accepted 1 June 2015

Available online 17 June 2015

\section{Keywords:}

Helper strain

Plant prebiotics

Pathobiome

Plant protection

\begin{abstract}
A B S T R A C T
Biocontrol research has long been focused on the study of single strains of biocontrol agents (BCAs) and on their interaction with pathogens and host plants. Further focus on plant-associated microbial communities was suggested several years ago, but significant advances only occurred recently. The advent of high-throughput sequencing (or next-generation sequencing - NGS) technologies is now driving a paradigm change that allows researchers to integrate microbial community studies into the traditional biocontrol approach. This integration could answer old scientific questions, and will raise new biocontrol hypotheses. Microbial communities could impact disease control through their interaction with host plants, pathogens, and BCAs. A better understanding of these interactions will provide unexpected opportunities to develop innovative biocontrol methods against plant pathogens. For example, formulation or timing of BCA application can be improved, "helper" microbial strains can be selected, or molecules driving the microbiota to a pathogen-resistant composition ("prebiotic" approach) can be developed. The five main challenges of microbiome implementation in biocontrol research are also described, i.e. (i) the management of technical errors and biases, (ii) the growing importance of bioinformatics, (iii) the adaptation of experimental schemes, (iv) the appropriate interplay between NGS and other technologies, and (v) the need to complete current genome databases.
\end{abstract}

(c) 2015 Elsevier Inc. All rights reserved.

\section{Introduction}

From a historical point of view, studies on plant-microbe interactions have so far mainly focused on binary or ternary interactions like plant-pathogen, plant-mycorrhizal fungi or plan t-pathogen-biocontrol agent. These studies significantly improved

\footnotetext{
* Corresponding author.

E-mail address: sebastien.massart@ulg.ac.be (S. Massart).
}

our understanding of these associations, but with a major drawback: plant roots and leaves harbor very diverse and abundant bacterial and fungal communities, so these interactions do not occur on a sterile surface as in most laboratory experiments. These communities are called microbiota when referring to the ecological community of microorganisms within a defined environment, or microbiome when referring to the collective genomes of all microorganisms from a given environmental niche. These microbial communities have been estimated at $10^{6}-10^{7}$ cells $/ \mathrm{cm}^{2}$ in 
the phyllosphere (Lindow and Brandl, 2003) and $10^{6}-10^{9}$ cells/g in the rhizosphere (Whitman et al., 1998).

Plants can therefore be considered as super organisms harboring very diverse microbial communities that provide specific functions and traits to plants. For more details, (de Bruijn, 2013) and (Vorholt, 2012) reviewed the role and function of the rhizosphere and phyllosphere microbial communities, respectively. These functions can be summarized as five key roles: (i) improving nutrient acquisition and growth, (ii) sustaining plant growth under biotic and/or abiotic stress, (iii) inducing resistance against pathogens, (iv) interacting with plant or human pathogens, and (v) interacting with other trophic levels like insects. The plant microbiota can be considered as a key factor for plant health and productivity. In parallel, plants drive microbiota selection through leaf or root anatomy and morphology or production of exudates.

Plant microbial communities hold a sizeable place in biological control as they are the source of the majority of biocontrol agents (BCAs). After washing and plating, cultivable microbes are isolated, and individual strains are screened for their biocontrol properties against plant pathogens. BCAs generated great enthusiasm as a sustainable control method of plant pathogens. Nevertheless, their practical application is often hampered by their lower or non-reproducible efficacy compared to chemical treatment. More comprehensive studies of BCA survival and efficacy on plants are still needed.

Research in biocontrol has mainly been focused on single BCA strains. Several authors suggested to focus more broadly on plant-associated microbial communities (Benítez and McSpadden Gardener, 2009; Kim et al., 2011; Smalla et al., 2001). However, this approach received little attention for the development of biocontrol methods. It was an unattainable objective due to the absence of techniques to survey microbial communities and their evolution in a holistic manner at affordable costs. Recent developments in high-throughput sequencing (or Next Generation Sequencing NGS) technologies and in bioinformatic analyses have drastically changed the course of events.

Many NGS technologies have been developed so far, and new technologies are still being developed. These technologies, their performances and limitations have been reviewed in detail elsewhere (Knief, 2014), so they will not be specifically addressed here. As far as microbial community studies are concerned, NGS methodologies can be divided into three approaches. Amplicon sequencing-based technologies are currently the most popular ones for plant microbiome studies. A specific genomic region is targeted, amplified and sequenced in order to describe the microbial community within a sample. Usually, the selected genes are the 16S rDNA gene for bacteria and the 18S rRNA gene or Internal Transcribed Spacer (ITS) region for fungi. Metagenome sequencing is a second approach. It is based on shotgun sequencing. DNA is extracted from the sample, sheared into small fragments, and directly sequenced. The sequences are further assembled into contigs and annotated. The third approach, called metatranscriptomics, is based on shotgun sequencing to study the gene transcripts of the whole microbial community. RNA is sheared, retrotranscribed, and then sequenced. Importantly, rRNA must be removed to focus the sequencing on other RNAs (messenger RNAs or non-coding RNAs). The sequences are further assembled into contigs and annotated. Recently, several studies using NGS, and mainly the amplicon approach, contributed to a more complete characterization of the composition of plant microbial communities. They boosted the interest for this neglected field and for the impact of these communities on plant growth, plant health and food safety. There are already several reviews on the impact of NGS on rhizosphere and phyllosphere microbial communities (Berlec, 2012; Bulgarelli et al., 2013; Knief, 2014; Rastogi et al., 2013).
The specific objective of this paper is to analyze the existing and future contribution of NGS technologies to plant microbiome studies in the context of biocontrol research, as illustrated in Fig. 1. In this figure, we underline the main emerging scientific questions related to the study of plant microbial communities and their effect on pathogens, plants and/or BCAs within the framework of biological control. Microbial communities may directly influence pathogen development through antibiosis, parasitism or competition. The microbiota may also have an indirect role by stimulating plant defenses or BCA survival and activity. A better understanding of the microbiome will also allow researchers to identify strains (considered as "helper microbial strains") or molecules (some could be considered as plant prebiotics) involved in improving these direct or indirect effects against plant pathogens. A better understanding of plant microbial community assembly, roles and ecosystem services could bring about unexpected opportunities to develop innovative control methods of plant pathogens.

\section{Available tools to study the plant microbiome}

In Fig. 2, the current tools used in microbiome studies are classified following two axes. The vertical axis corresponds to the focal degree of the approach from a single target to a holistic analysis. The horizontal axis classifies approaches depending on the information they provide: from community description and characterization to functional analysis of community member interactions.

This figure illustrates the opportunities offered by NGS technologies. For the first time, it is possible to study microbial communities at a very fine resolution while using holistic approaches. These advances were made possible by huge research projects on the human microbiome, but also by the Earth Microbiome Project (www.earthmicrobiome.org), a massive multidisciplinary effort to analyze microbial communities across the globe. The project aims to sequence and analyze 200,000 samples from these communities to produce a global Gene Atlas describing gene functions, proteins, and environmental metabolic models for each biome. The Earth Microbiome Project also releases protocols and standards for sample preparation and data analysis.

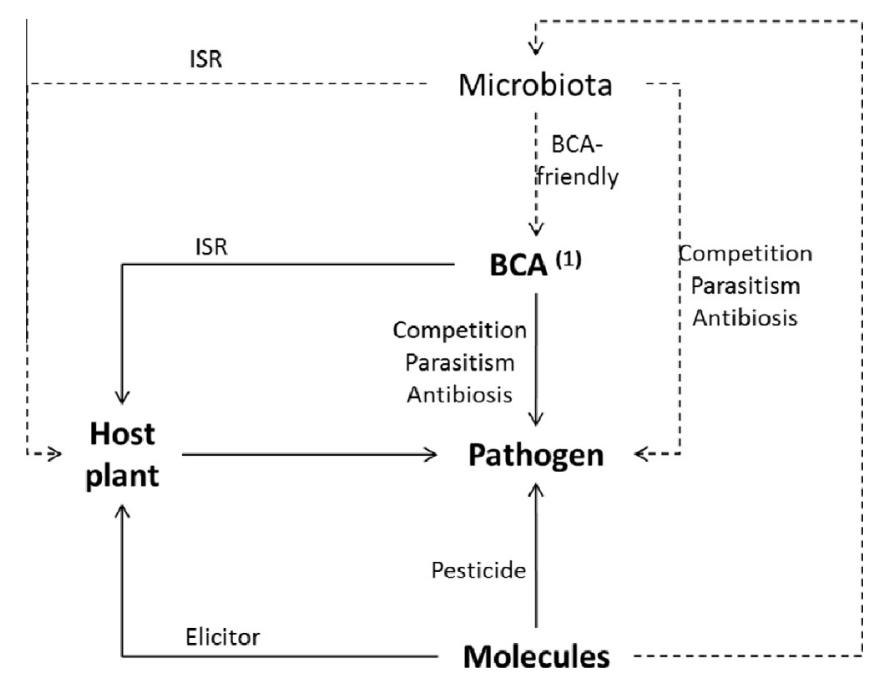

Fig. 1. Current and future roles of the microbiota in the control of plant pathogens. Full arrows represent current research areas and control measures. Dotted arrows correspond to future research areas and control measures that can arise from a better understanding of the role of the microbiota using NGS methodologies. ISR: induced systemic resistance. (1): BCAs are frequently isolated from plant microbiota. 


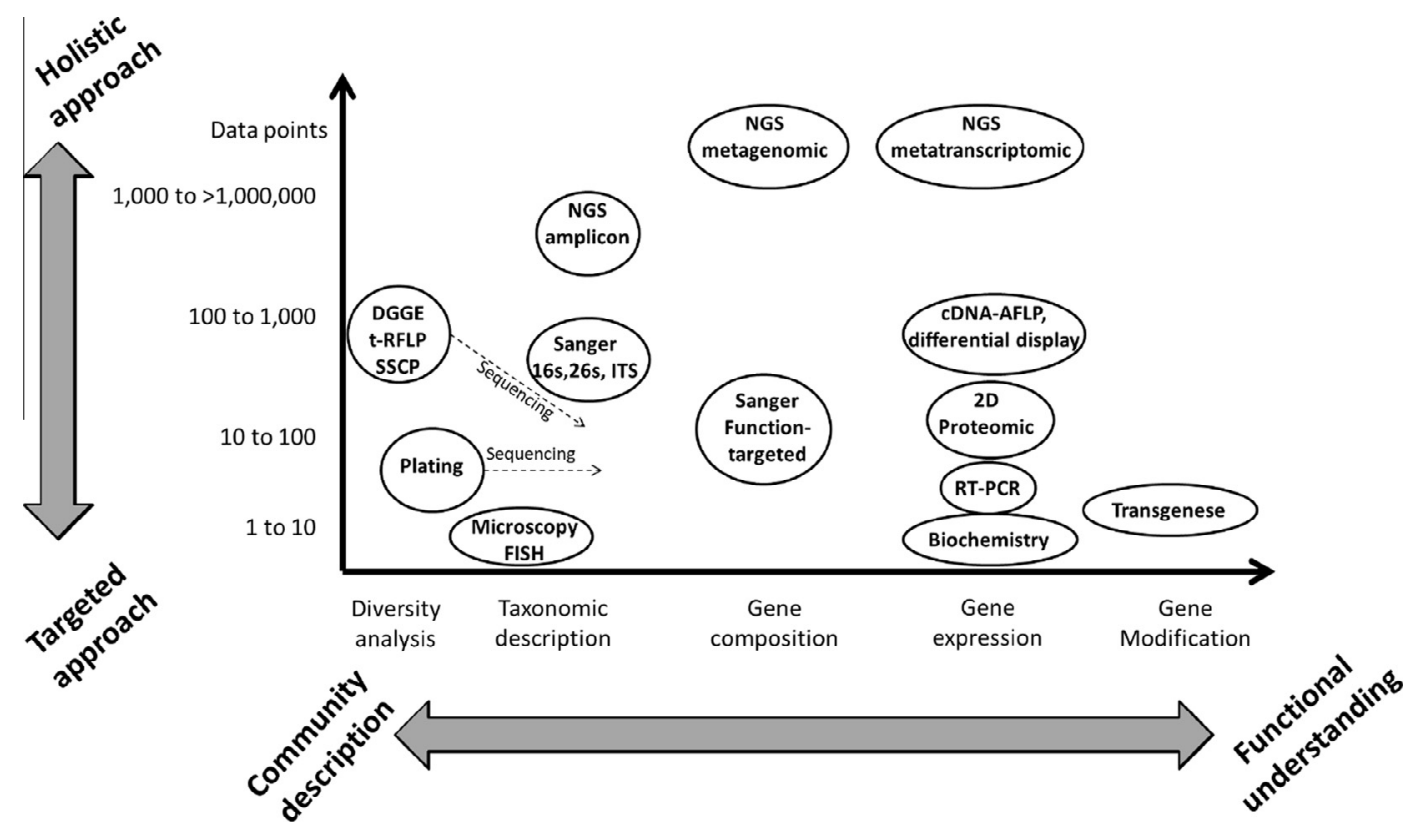

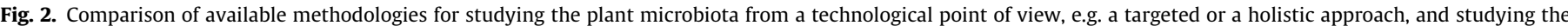

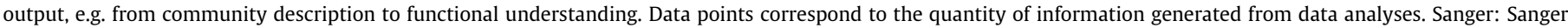

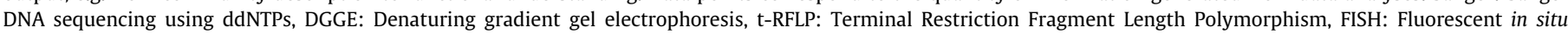
hybridization, cDNA-AFLP: cDNA - amplified fragment-length polymorphism.

The three approaches based on NGS technologies are detailed and compared in Table 1 . The amplicon sequencing approach is cheaper and easier to carry on and interpret, but only provides information at the taxonomic level. Sequences are clustered into Operational Taxonomy Units (OTUs), which represent species or groups of closely related species. These OTUs are further assigned to their most probable taxonomical levels and thus provide an overview of species diversity and abundance in each sample (alpha-diversity). Moreover, beta-diversity analyses are carried out. They calculate the degree of similarity, e.g. phylogenetic relatedness, between samples and/or groups of samples. Amplicon sequencing does not provide any information about genes, whether present in the genome of microorganisms or transcribed. The metagenome sequencing approach corresponds to the direct sequencing of the DNA extracted from microbial communities without targeting any specific gene. It provides the gene content of a microbial population. The generated sequences are aligned, a process called de novo assembly, to reconstruct the genes and genomes. Metagenome sequencing will not allow for the sequencing of entire genomes. The size of the assembled sequences, called contigs, can greatly vary, from a few hundred to several hundred thousand nucleotides. The genes present in contigs can further be identified by comparing their sequences to databases. Based on gene functions, microbiome pathways can further be reconstructed and analyzed in depth. Yet, there is still a bias as a highly abundant gene in the microbiome is not necessarily highly expressed. The metatranscriptomics approach is a functional supplement of the metagenomics approach. By studying microbial community gene transcripts, the metatranscriptomics approach identifies the most transcribed genes and pathways. This refines the functional understanding of microbiota roles and functions. This approach has not yet been applied to plant microbiomes, but it is becoming more popular in the more advanced field of human microbiome studies.

The application of these emerging NGS approaches in biocontrol research will lead to a better understanding of the role of the microbiota in pathogen control. As illustrated in Fig. 1, NGS approaches analyzing plant microbiomes will address new research areas like the role of the microbiota in plant defense, the trophic interactions between microbiota and pathogens or BCAs, the development of molecules to modulate the microbiota toward a "pathogen-hostile" state... Importantly, NGS technologies should not be seen as competitors of classical approaches like microbiology, biochemistry or low-throughput molecular biology (Sanger sequencing, real-time PCR, FISH....). When applied within an appropriate experimental design, NGS will generate innovative and strong hypotheses about relationships between microbiota, plant, BCA and pathogen. These hypotheses will have to be later verified and confirmed, mainly through microbiological, biochemical or classical molecular biology approaches. For example, microscopy technologies, like FISH-CLSM, have already been used to confirm hypotheses of taxon co-occurrence or co-exclusion raised by NGS (Bragina et al., 2014; Cardinale et al., 2015). For biocontrol research, it is possible to investigate if a BCA colocalizes with other taxa whose presence correlates with improved or more stable biocontrol efficacy. Strains from these taxa could further be selected as "helper microbial strain" for the BCA (described later in the text).

\section{Driving factors of the rhizosphere and phyllosphere microbiomes}

Phyllosphere, rhizosphere and soil microbial communities are significantly different in terms of species composition, abundance and diversity (Bulgarelli et al., 2013; Inceoğlu et al., 2011; Martins et al., 2013). The main drivers of the rhizosphere microbiome are soil type and plant genotype (Berg and Smalla, 2009; de Bruijn, 2013). Soil type is particularly important through its composition and physicochemical properties. Soils represent the major sources of microbes for the rhizosphere. Plant species and genotype also modulate the microbiota through root morphology and physiology, root exudate composition, and the presence of defense genes. Additionally, the rhizosphere microbiome can also 
Table 1

Comparison of the 3 existing approaches for microbiome study by NGS. PCA: Principal Component Analysis; NMDS: Non Metric Multidimensional Scaling.

\begin{tabular}{|c|c|c|c|}
\hline Approach & Amplicon & Metagenome & Metatranscriptome \\
\hline $\begin{array}{l}\text { Nucleic acids } \\
\text { target }\end{array}$ & DNA & DNA & RNA \\
\hline $\begin{array}{l}\text { Laboratory } \\
\text { steps }\end{array}$ & $\begin{array}{l}\text { PCR amplification with selected primers } \\
\text { High throughput sequencing }\end{array}$ & DNA shearing and library preparation & RNA shearing and library preparation \\
\hline $\begin{array}{l}\text { Generated } \\
\text { sequences }\end{array}$ & Thousands & Millions & Millions \\
\hline \multirow{3}{*}{$\begin{array}{l}\text { Basic data } \\
\text { analysis }\end{array}$} & \multicolumn{3}{|l|}{ Quality control of the sequences } \\
\hline & Clustering of the sequences in OTUs & \multicolumn{2}{|l|}{ Alignment of the sequences in contigs or scaffolds } \\
\hline & Taxonomic assignation of the OTUs & \multicolumn{2}{|l|}{ Taxonomic and functional assignation of the contigs } \\
\hline \multirow{4}{*}{$\begin{array}{l}\text { Advanced } \\
\text { data } \\
\text { analysis }\end{array}$} & \multicolumn{2}{|c|}{ Alpha-diversity analysis (richness, diversity...) } & - \\
\hline & - & \multicolumn{2}{|c|}{ Gene and metabolic pathways characterization and quantification } \\
\hline & $\begin{array}{l}\text { Sample comparison (taxa presence and } \\
\text { abundance, diversity indexes) }\end{array}$ & $\begin{array}{l}\text { Sample comparison (taxa, genes and metabolic pathways } \\
\text { presence and abundance) }\end{array}$ & $\begin{array}{l}\text { Sample comparison (genes and metabolic } \\
\text { pathways differential expression) }\end{array}$ \\
\hline & \multicolumn{3}{|c|}{ Beta-diversity analysis (NMDS, PCA, Box-plot) } \\
\hline \multirow[t]{2}{*}{ Output } & $\begin{array}{l}\text { Taxonomic abundance and diversity of the } \\
\text { microbiome }\end{array}$ & Taxonomic abundance and diversity of the microbiome & $\begin{array}{l}\text { Taxonomic abundance and diversity of the } \\
\text { living microbiome }\end{array}$ \\
\hline & - & $\begin{array}{l}\text { Overview on the functions and pathways present in the } \\
\text { microbiome }\end{array}$ & $\begin{array}{l}\text { Overview on the functions and pathways } \\
\text { transcribed in the microbiome }\end{array}$ \\
\hline \multirow[t]{3}{*}{ Advantages } & $\begin{array}{l}\text { Simpler bioinformatic analysis is without } \\
\text { high computing power }\end{array}$ & $\begin{array}{l}\text { Functional analysis of the microbiome at genes and } \\
\text { pathway levels }\end{array}$ & $\begin{array}{l}\text { Functional analysis of the living } \\
\text { microbiome at genes and pathway levels }\end{array}$ \\
\hline & Easy interpretation of the data & More in depth analysis of strain composition and diversity & $\begin{array}{l}\text { Better understanding of microbiome } \\
\text { functions }\end{array}$ \\
\hline & Low cost & & \\
\hline \multirow[t]{4}{*}{ Drawbacks } & Analysis of dead cells and free DNA & Analysis of dead cells and free DNA & $\begin{array}{l}\text { Technically the most challenging in the } \\
\text { laboratory }\end{array}$ \\
\hline & $\begin{array}{l}\text { No functional information on the genes } \\
\text { and pathways }\end{array}$ & $\begin{array}{l}\text { The presence and abundance of a gene/pathway not } \\
\text { always correlated with transcription level }\end{array}$ & $\begin{array}{l}\text { More challenging bioinformatic analysis } \\
\text { than metagenome analysis }\end{array}$ \\
\hline & & $\begin{array}{l}\text { More challenging bioinformatic analysis than amplicon } \\
\text { analysis }\end{array}$ & Higher cost \\
\hline & & Higher cost & \\
\hline
\end{tabular}

be influenced by fertilizers (Ikeda et al., 2011), crop rotation (Hilton et al., 2013), and pesticides (Jacobsen and Hjelmsø, 2014).

The phyllosphere microbiome is also mainly influenced by plant species and genotype. Key factors are the chemical composition of the cuticle, the presence of veins, stomata or surface appendages like trichomes (Vorholt, 2012). The genotype is also particularly important. For example, a single mutation in a plant gene, like lacs2 and pec1 in Arabidopsis thaliana, can modify the microbiome (Bodenhausen et al., 2014). Moreover, environmental factors, such as, UV exposure and air humidity, and geographical location, also influence microbiome composition (Rastogi et al., 2013; Vorholt, 2012). Geographical location has been identified as a main driver in a lettuce field (Rastogi et al., 2012), but not in trees (Redford et al., 2010). Other factors are the growing season (Rastogi et al., 2012), nitrogen fertilization (Ikeda et al., 2011), and pesticide application (Moulas et al., 2013; Walter et al., 2007; Zhang et al., 2009).

\section{Microbiome responses to BCAs or pathogen application}

Once applied, BCAs encounter and interact with very diverse microbial communities depending on plant species, environmental factors and localization. The influence of a single microorganism on the microbial community has already been studied for plant pathogens and/or BCAs. These studies were carried out using either classical methodologies and/or NGS. They are summarized in Table 2.

First, the exponential growth of publications in this field over the last three years underlines the raising interest of the scientific community. The effect of BCAs on the rhizosphere microbiome has been much more studied than the effect of BCAs on the phyllosphere microbiome.

Several studies evidenced that factors like soil properties, experimental conditions and physiological state had a deeper and more durable effect on the rhizosphere microbiota than
BCA application (Chowdhury et al., 2013; Grosch et al., 2006; Kröber et al., 2014; Scherwinski et al., 2007; Schreiter et al., 2014b). The effect of a BCA can also depend on its interaction with other factors: amplicon sequencing analysis revealed significant modifications of the bacterial community composition of lettuce rhizosphere following application of the BCA P. jessenii RU47 in alluvial loam, but not in diluvial sand or loess loam (Schreiter et al., 2014a).

The methodology used to study the plant microbiome can impact the experimental outcomes. Plating and low-throughput molecular techniques showed that BCA treatment altered microbial community diversity and abundance. (Buddrus-Schiemann et al., 2010; Chowdhury et al., 2013; Teixidó et al., 1998; Yin et al., 2013; Zhang et al., 2008). These results show that a BCA has an impact on the plant microbiome. Two recent publications compared the results obtained using NGS and low-throughput approaches (Schmidt et al., 2014b; Sylla et al., 2013). They both showed that classical techniques failed to detect alterations in microbial communities found when using NGS technologies. These examples show that NGS technologies provide a more holistic and in-depth analysis of the microbiome, and could therefore be much more appropriate to detect alterations in microbial community diversity and abundance after BCA treatment. As a consequence, the results of some publications using low-throughput technologies and underlining the absence of effect of a BCA should be taken with care or would need further confirmation from NGS tools.

The comparative impact of a BCA and a pathogen on the plant microbiome has also been studied by classical low-through put molecular biology and NGS. Compared to untreated plants, $R$. solani caused much higher dissimilarity in lettuce rhizosphere bacterial communities than BCA application (Trichoderma sp.) (Grosch et al., 2006). $R$. solani severely affected the bacterial and fungal community structure of lettuce rhizosphere, while the BCA Pseudomonas jessenii RU47 had a much smaller effect (Adesina et al., 2009). Application of B. amyloliquefaciens FZB42 to the soil 
Table 2

Impact of BCA application on the microbiota of a plant.

\begin{tabular}{|c|c|c|c|c|c|c|c|}
\hline Plant & Organ $^{1}$ & BCA application & $\begin{array}{l}\text { Pathogen } \\
\text { inoculation }\end{array}$ & Target $^{2}$ & Technology & Observation & References \\
\hline Apple & Fruit & Candida sake CPA-1 & - & F \& B & Plating & $\begin{array}{l}\text { White yeasts, Cladosporium spp. and } \\
\text { Penicillium spp. were significantly } \\
\text { reduced compared to untreated controls, } \\
\text { while the bacterial population remained } \\
\text { similar throughout the apple storage } \\
\text { period ( } 7 \text { months) }\end{array}$ & $\begin{array}{l}\text { Teixidó et al. } \\
\text { (1998) }\end{array}$ \\
\hline Barley & $\mathrm{R}$ & Pseudomonas spp. DSMZ13134 & - & B & t-RFLP & $\begin{array}{l}\text { Microbiota was transiently modified up } \\
\text { to } 3 \text { weeks after treatment }\end{array}$ & $\begin{array}{l}\text { Buddrus- } \\
\text { Schiemann } \\
\text { et al. (2010) }\end{array}$ \\
\hline Chamomille & $\mathrm{R}$ & $\begin{array}{l}\text { Streptomyces subrutilus Wbn2-11, Bacillus } \\
\text { subtilis Co1-6, Paenibacillus polymyxa } \\
\text { Mc5Re-14, P. fluorescens L13-6-12, } \\
\text { Stenotrophomonas rhizophila P69, Serratia } \\
\text { plymuthica 3Re4-18 }\end{array}$ & - & B & $\begin{array}{l}\text { Sanger, PCR } \\
\text { and } \\
\text { Amplicon } \\
\text { NGS }\end{array}$ & $\begin{array}{l}\text { Low throughput analyses of } 16 \mathrm{~S} \text { rDNA } \\
\text { and real-time PCR did not show } \\
\text { significant differences between each BCA } \\
\text { and the control. By contrast, high } \\
\text { throughput sequencing of } 16 \mathrm{~S} \text { rDNA } \\
\text { revealed significant differences in the } \\
\text { community structure of bacteria } 4 \text { and } \\
8 \text { weeks after the treatments }\end{array}$ & $\begin{array}{l}\text { Schmidt } \\
\text { et al. (2014) }\end{array}$ \\
\hline Cucumber & $\mathrm{R}$ & Suppressive soil & - & F \& B & $\begin{array}{l}\text { Amplicon } \\
\text { NGS }\end{array}$ & $\begin{array}{l}\text { Massilia spp populations were reduced, } \\
\text { while Rhizobium spp., Bacillus spp., } \\
\text { Paenibacillus spp., and Streptomyces spp. } \\
\text { (genera including species described as } \\
\text { fungal antagonists) increased. Changes } \\
\text { were observed } 3 \text { and } 6 \text { days after } \\
\text { treatment }\end{array}$ & $\begin{array}{l}\text { Klein et al. } \\
(2012)\end{array}$ \\
\hline Cucumber & $\mathrm{R}$ & B. subtilis B579 & - & B & $\begin{array}{l}\text { Plating and } \\
\text { DGGE }\end{array}$ & $\begin{array}{l}\text { There was a minimal and transient effect } \\
\text { on rhizosphere bacterial population } \\
\text { structure } 4 \text { and } 9 \text { weeks after treatment }\end{array}$ & $\begin{array}{l}\text { Chen et al. } \\
\text { (2013) }\end{array}$ \\
\hline Cucumber & $\mathrm{R}$ & P. fluorescens $2 \mathrm{P} 24$ and CPF10 & - & B & $\begin{array}{l}\text { DGGE and t- } \\
\text { RFLP }\end{array}$ & $\begin{array}{l}\text { Bacterial population structure was } \\
\text { transiently modified after treatment. } \\
\text { Differences with the control disappeared } \\
\text { after } 8 \text { weeks }\end{array}$ & $\begin{array}{l}\text { Yin et al. } \\
(2013)\end{array}$ \\
\hline Lettuce & $\mathrm{R}$ & Trichoderma sp. & R. solani & F \& B & SCCP, Sanger & $\begin{array}{l}\text { Pathogen and plant developmental } \\
\text { stagehad much more influence on } \\
\text { microbiota composition than BCA } \\
\text { treatment after } 4 \text { and } 16 \text { weeks }\end{array}$ & $\begin{array}{l}\text { Grosch et al. } \\
(2006)\end{array}$ \\
\hline Lettuce & $\mathrm{R}$ & P. jessenii RU47 and 14 other BCAs & R. solani & $\mathrm{F} \& \mathrm{~B}$ & DGGE & $\begin{array}{l}\text { Pathogen inoculation severely affected } \\
\text { microbial communities, while BCA had a } \\
\text { much less pronounced effect } 5 \text { and } \\
7 \text { weeks after treatment }\end{array}$ & $\begin{array}{l}\text { Adesina } \\
\text { et al. (2009) }\end{array}$ \\
\hline Lettuce & $\mathrm{R}$ & T. viride GB7 S. plymuthica 3Re4-18 & R. solani & B & DGGE & $\begin{array}{l}\text { Co-inoculation improved biocontrol } \\
\text { efficacy and had a more pronounced } \\
\text { effect on microbial community structure } \\
\text { (increased evenness) } 2 \text { and } 4 \text { weeks after } \\
\text { treatment }\end{array}$ & $\begin{array}{l}\text { Grosch et al. } \\
(2012)\end{array}$ \\
\hline Lettuce & $\mathrm{R}$ & B. amyloliquefaciens FZB42 & $\begin{array}{l}\text { Rhizoctonia } \\
\text { solani }\end{array}$ & B & t-RFLP & $\begin{array}{l}\text { There was a clear temporal shift but no } \\
\text { long-term major impact of BCA after } \\
5 \text { weeks. } R \text {. solani affected the } \\
\text { rhizosphere microbial community after } \\
\text { inoculation }\end{array}$ & $\begin{array}{l}\text { Chowdhury } \\
\text { et al. (2013)) }\end{array}$ \\
\hline Lettuce & $\mathrm{R}$ & B. amyloliquefaciens FZB42 & R. solani & B & $\begin{array}{l}\text { Amplicon } \\
\text { NGS }\end{array}$ & $\begin{array}{l}\text { The plant microbiota shifted as a } \\
\text { consequence of pathogen attack, but } \\
\text { these effects were offset by FZB } 42\end{array}$ & $\begin{array}{l}\text { Erlacher } \\
\text { et al. (2014) }\end{array}$ \\
\hline Lettuce & $\mathrm{R}$ & B. amyloliquefaciens FZB42 & - & All & $\begin{array}{l}\text { Metagenome } \\
\text { NGS }\end{array}$ & $\begin{array}{l}\text { No major taxonomic or functional } \\
\text { differences were observed in the } \\
\text { rhizosphere microbiota } 2 \text { and } 5 \text { weeks } \\
\text { after treatment }\end{array}$ & $\begin{array}{l}\text { Kröber et al. } \\
(2014)\end{array}$ \\
\hline Lettuce & $\mathrm{R}$ & $\begin{array}{l}\text { P. jessenii RU47, Serratia plymuthica } \\
\text { 3Re4-18 }\end{array}$ & - & B & DGGE & $\begin{array}{l}\text { No significant modification of the } \\
\text { rhizosphere microbial communities was } \\
\text { recorded after } 2 \text { and } 5 \text { weeks }\end{array}$ & $\begin{array}{l}\text { Schreiter } \\
\text { et al. } \\
\text { (2014b) }\end{array}$ \\
\hline Lettuce & $\mathrm{R}$ & P. jessenii RU47 & - & B & $\begin{array}{l}\text { Amplicon } \\
\text { NGS }\end{array}$ & $\begin{array}{l}\text { Soil type influenced the impact of BCA on } \\
\text { the rhizosphere microbiota } 2 \text { or } 3 \text { weeks } \\
\text { after treatment }\end{array}$ & $\begin{array}{l}\text { Schreiter } \\
\text { et al. } \\
\text { (2014a) }\end{array}$ \\
\hline Pepper & $\mathrm{P}$ & B. thuringiensis & - & B & PLFA, DGGE & $\begin{array}{l}\text { PLFA analysis suggested that bacterial } \\
\text { biomass and fungal biomass were not } \\
\text { significantly affected following BCA } \\
\text { application. But principal component } \\
\text { analysis of PLFA data and DGGE indicated } \\
\text { that the phyllosphere microbial } \\
\text { community structure was significantly } \\
\text { affected }\end{array}$ & $\begin{array}{l}\text { Zhang et al. } \\
\text { (2008) }\end{array}$ \\
\hline Pepper & $\mathrm{R}$ & $\begin{array}{l}\text { P. corrugata CCR80, Chryseobacterium } \\
\text { indologenes ISE14 }\end{array}$ & - & $\mathrm{F} \& \mathrm{~B}$ & $\begin{array}{l}\text { Plating, } \\
\text { DGGE }\end{array}$ & $\begin{array}{l}\text { Both strains modified bacterial and } \\
\text { fungal community composition, but this } \\
\text { effect disappeared after } 80 \text { days for the } \\
\text { fungal community }\end{array}$ & $\begin{array}{l}\text { Sang and } \\
\text { Kim (2012) }\end{array}$ \\
\hline
\end{tabular}


Table 2 (continued)

\begin{tabular}{|c|c|c|c|c|c|c|c|}
\hline Plant & Organ $^{1}$ & BCA application & $\begin{array}{l}\text { Pathogen } \\
\text { inoculation }\end{array}$ & Target $^{2}$ & Technology & Observation & References \\
\hline Strawberry & $\mathrm{R}$ & $\begin{array}{l}\text { S. plymuthica HRO-C48, Streptomyces sp. } \\
\text { HRO-71 }\end{array}$ & - & $\mathrm{F} \& \mathrm{~B}$ & Plating, SSCP & $\begin{array}{l}\text { There was no major long-term impact of } \\
\text { BCA treatments on the rhizosphere } \\
\text { microbiota }\end{array}$ & $\begin{array}{l}\text { Scherwinski } \\
\text { et al. (2007) }\end{array}$ \\
\hline Strawberry & $\mathrm{P}$ & $\begin{array}{l}\text { B. amyloliquefaciens FZB42, T. harzianum } \\
\text { T22, Beauveria bassiana ATCC } 74040\end{array}$ & - & F \& B & $\begin{array}{l}\text { Plating, } \\
\text { amplicon } \\
\text { NGS }\end{array}$ & $\begin{array}{l}\text { Plate counts did not reveal any changes, } \\
\text { but high throughput sequencing of ITS } \\
\text { and } 16 S \text { rDNA revealed a modification of } \\
\text { the fungal population (composition and } \\
\text { diversity) with T. harzianum, while } \\
\text { bacterial diversity was not affected by } \\
\text { any of the } 3 \text { BCAs one month after } \\
\text { treatment }\end{array}$ & $\begin{array}{l}\text { Sylla et al. } \\
\text { (2013b) }\end{array}$ \\
\hline Strawberry & $\mathrm{P}$ & $\begin{array}{l}\text { Aureobasidium pullulans DSM } 14940 \text { and } \\
\text { DSM } 14941\end{array}$ & - & F \& B & $\begin{array}{l}\text { Plating, } \\
\text { amplicon } \\
\text { NGS }\end{array}$ & $\begin{array}{l}\text { BCA establishment followed inter-annual } \\
\text { variations. Weekly BCA applications had } \\
\text { an effect on fungal communities. These } \\
\text { effects might be negligible compared to } \\
\text { natural microbiota variation }\end{array}$ & $\begin{array}{l}\text { Sylla et al. } \\
\text { (2013a) }\end{array}$ \\
\hline Grapevine & $\mathrm{P}$ & Lysobacter capsici AZ78 & - & F \& B & $\begin{array}{l}\text { Amplicon } \\
\text { NGS }\end{array}$ & $\begin{array}{l}\text { Richness and diversity of bacterial and } \\
\text { fungal populations were only minimally } \\
\text { affected after three weekly treatments }\end{array}$ & $\begin{array}{l}\text { Perazzolli } \\
\text { et al. (2014) }\end{array}$ \\
\hline
\end{tabular}

\footnotetext{
1 Organ studied with $\mathrm{R}=$ rhizosphere and $\mathrm{P}=$ phyllosphere.

${ }^{2}$ F = fungi and B = eubacteria. SSCP: single-strand conformation polymorphism; Sanger: sequencing with chain-terminating dideoxynucleotides; PFLA: phospholipid fatty
} acid; CLPP: Community Level Physiological Profile; DGGE: denaturing gradient gel electrophoresis; t-RFLP: terminal Restriction Fragment Length Polymorphism.

did not cause major shifts in the microbial communities of lettuce rhizosphere, while $R$. solani inoculation affected the rhizosphere bacterial population structure (Chowdhury et al. (2013). The impact of the pathogen $R$. solani and/or of the BCA strain FZB42 on phyllosphere and rhizosphere bacterial communities of lettuce was also studied more in depth by amplicon sequencing (Erlacher et al., 2014). The plant microbiota shifted as a consequence of pathogen attack, but these effects were offset by FZB42. These results suggest a novel mode of action for the BCA, i.e. selective compensation of the impact of a pathogen on the plant-associated microbiota by the phyllosphere and rhizosphere. It is worth mentioning that this effect could originate from the direct impact of the BCA on the microbiota or from an indirect impact of pathogen control by the BCA. Compared to single strain application, co-inoculation of two different BCAs caused a more pronounced impact on the microbial community structure of cucumber rhizosphere, with increased evenness and better biocontrol of $R$. solani (Grosch et al., 2012). Microbiome analysis is often supplemented by specific detection and quantification of the BCA and/or the pathogen. Importantly, when a pathogen is inoculated, symptoms should be recorded in detail throughout the experiment in parallel with microbiome analysis, during and after microbiome sampling. The appearance of symptoms might significantly modify environmental conditions, and in turn impact microbial community diversity and abundance. (Erlacher et al., 2014) found contrasting results, with not clearcut difference between the rhizospheres of diseased ( $R$. solani) and healthy lettuce plants, but with microbial community structure alterations in the phyllosphere of diseased plants. The disease status of plants needs to be clearly stated in publications comparing the impact of a BCA and of a pathogen on microbial communities.

Several publications identified a transient modification of the plant microbiota after BCA application (Buddrus-Schiemann et al., 2010; Chen et al., 2013; Chowdhury et al., 2013; Scherwinski et al., 2007; Yin et al., 2013). However, microbial community composition returned to a similar state to the untreated control over time. If combined with effective biocontrol of the pathogen, these observations may confirm that BCA application represents an ecologically-friendly treatment against pathogens, with minimal or null impact on resident microbial populations over time.

\section{Opportunities for biocontrol research in the microbiome era}

Through their impact on the development of next-generation bio-products, NGS technologies are already an important driver of innovation toward a sustainable agriculture (Berg et al., 2013). The advantages of NGS technologies over classical techniques for microbial community studies are illustrated in Fig. 2. They rely mainly on their ability to provide a holistic view of microbial community composition and functions. This holistic approach is particularly interesting to identify specific, and sometimes unexpected, features of the microbiome (presence of species, genes or pathways, expressed genes...) in relation with the presence, survival or development of a plant pathogen or a BCA. This combination of microbial community features with information on disease incidence or severity is essential to generate new hypotheses and develop more mechanistic studies. NGS approaches can identify changes in the microbiome that went unnoticed using classical techniques (Schmidt et al., 2014b; Sylla et al., 2013). NGS approaches can therefore give a much better and more detailed picture of microbiome evolution. Altogether, this provides innovative tools to answer old scientific questions, for example whether BCAs and/or pathogens modify microbial community richness and diversity; whether the lack of efficacy of BCAs is due to microbial community composition at the time of application or to a microbial shift favoring pathogen microbes after BCA treatment; what the role of microbial communities in plant immunity and in pathogen development is. It will also raise new scientific questions, i.e. whether BCAs modify the microbial community toward a pathogen-adverse composition; how and when apply a BCA to leverage its effect through microbial communities; which external factors, such as nutrients, can favor beneficial microbiota; whether we can develop softer methods of control based on the stimulation of endogenous beneficial microbiota.

Current publications on plant microbiomes are mainly focused on the taxonomical description of microbial communities. First studies were only focused on bacteria through $16 \mathrm{~S}$ rDNA sequencing, while more recent studies also include fungal screening (Perazzolli et al., 2014; Sylla et al., 2013). Knowing the role of fungi in plant health and productivity, the simultaneous analysis of bacterial and fungal communities can now be considered as mandatory for any plant microbiome study focused on biocontrol 
agents and/or plant pathogens. Moreover, the taxonomical level used to describe and compare samples is crucial to spot differences. Two recent studies observed variation between sample groups only at the genus or lower taxonomical levels, while no differences were observed at the phylum level (Degrune et al., 2015; Schmidt et al., 2014a). Both publications underlined that the use of the genus or lowest possible taxonomical level could be more appropriate to detect differences in microbial communities.

Even if valuable information can be gained at the phylum, family, genus or even species levels through taxonomic description, conclusions are limited by the lack of any functional information. The role of the observed phyla can only be inferred from the literature. Microorganisms exhibit an astonishing diversity and wide genetic variability even within species, especially with respect to their metabolic pathways and host-interactive capabilities (Dini-Andreote and van Elsas, 2013). The next research step now emerging in plant microbiome studies is to develop functional analysis through metagenome sequencing. This approach will identify the genes present in the plant microbiome and will allow for a pathway-based functional analysis of metagenomes. Such functional analysis could yield a more accurate description and a refined understanding of the role of the microbiome in the biocontrol of plant pathogens. For example, conserved functions in these communities or functions linked with pathogen development or plant resistance will be identified. Metagenomic sequencing is a valuable approach to identify unique features of phyllosphere or rhizosphere microorganisms, as well as so far undescribed mechanisms of plant-microbe and microbe-microbe interactions. This approach has already been used to gain a better understanding of and new insights into the functions of the human microbiome, and into its co-evolution with the hosts and their environment (Arumugam et al., 2011; Qin et al., 2010; Yatsunenko et al., 2012). For example, (Tong et al., 2013) identified groups of genes essential for life in the human gut that were conserved across functional microbial communities (e.g. carbohydrate and amino acid metabolism), whereas several virulent pathways (including bacterial invasion, pathogenic E. coli infection) were enriched in functional microbial communities associated with Inflammatory Bowel Syndrom. Functional biomarkers derived from metagenome sequencing may be more robust than phylogenetic ones in finding correlations between microbial community and human host characteristics (Qin et al., 2010). Then, the presence and persistence of functions in the plant microbiome might also be more important than taxonomical persistence. In a pioneering experiment, (Cardinale et al., 2015; Kröber et al., 2014) compared a rhizosphere microbiome at the taxonomical and functional levels, with or without applying BCA FBZ42. At the functional level, they focused their interpretation on subsystems involved in the utilization and metabolism of plant root exudates like carbohydrates, nitrogen and amino acid metabolic pathways, or involved in antibiotic resistance and in the transport system for toxic compounds. They observed minor changes with time in carbohydrate metabolism, depending on the growth state of the plant, and no major difference due to BCA application. Nevertheless, they compared only one pooled sample for each condition, without any replicate, so statistical comparison between samples is limited. This observation underlines that metagenomics sequencing of replicates of each condition is highly recommended to make relevant statistical comparisons between conditions, even if it significantly impacts budgets. Functional characterization of the microbiome also relies on gene expression studies. Based on metagenomics data, the expression of a limited number of genes potentially important in the plant-microbiome-BCA interaction can be further studied by techniques such as real-time quantitative RT-PCR (RT-QPCR). Additionally, using high-throughput sequencing of the whole transcriptome, one can analyze shifts at the transcription level of the microbiome. Integrating metagenomics and metatranscriptomics data is particularly important because the highly abundant genes in genomes are not systematically the most expressed ones (Franzosa et al., 2014).

We anticipate that the application of these new approaches will impact biocontrol research in five ways. First, NGS approaches will contribute to increasing knowledge about microbial community development and evolution with time, e.g. through various physiological state, pathogenicity and environmental conditions. This increased understanding will allow for novel control methods to be designed and tested to modify this process toward a plant-friendly or BCA-friendly microbial community that will interfere with pathogen establishment and development, and with disease development.

Second, NGS technologies may identify new relationships between the microbial community and the presence of pathogens or an inoculated BCA without a priori. For example, the sequencing of the lettuce phyllosphere microbiome showed that the foliar presence of Xanthomonas campestris pv. vitians, the causal agent of bacterial leaf spot of lettuce, correlated positively with the presence of bacteria from the genus Alkanindiges, but negatively with Bacillus, Erwinia and Pantoea (Rastogi et al., 2012). In human clinical research, the effects of pathogen infection on gut microbiota and its consequences on the host have been more extensively studied by NGS of resident microbiota. For example, a shift in microbial structure occurred during infection by bacterial or viral pathogens (Chassaing et al., 2013; Nelson et al., 2012) These studies also underline the importance of syntrophic relationships between taxa in different environmental conditions and warrant trans-kingdom studies of the plant microbiome (bacteria, fungi, virus).

Third, microbial communities can have an effect on the applied $\mathrm{BCA}$, but also on plant pathogens, through various trophic interactions such as antagonism, commensalism or mutualism. More precisely, the antagonistic effect of microbial communities against plant pathogens could occur through nutrient or site competition, antibiosis, direct interaction with the pathogen and induction of host resistance. Assembling artificial core microbiomes corresponding to a mix of bacterial strains, and applying them to plant disease control has been suggested (Gopal et al., 2013). This approach can be refined: instead of applying a mix of several bacterial strains, we could try to identify, select and produce helper microbial strains. A helper microbial strain does not have biocontrol properties per se. It only facilitates or enhances biocontrol properties through, for example, better BCA establishment or survival on the host, or improved metabolite production by BCAs. Microbiome and colocalization studies could therefore provide a scientific basis for selecting such helper strains to improve biocontrol reliability and efficacy. Moreover, we wish to suggest another approach, by analogy with human nutrition. A new concept can emerge in the biocontrol field: the probiotic approach, based on individual or combined application of beneficial strains, can evolve toward a prebiotic approach based on the application of molecules driving the plant microbiota toward a composition limiting the development of plant pathogens. It is worth mentioning that the development and application of molecules have several advantages compared to living BCAs: easier registration (at least for the EFSA at the European level), easier manufacturing, stability, and easier application of the commercial product. A better understanding of the interactions between plant pathogens and microbial communities, also referred to as pathobiome (Vayssier-Taussat et al., 2014), could lead to the identification and development of molecules or cultural practices able to favor a microbiota protecting a plant against a pathogen. These molecules could be applied alone or in combination with a BCA or plant elicitors and defense primers in order to maximize the efficiency of these alternative protection methods. The efficacy and reliability of these molecules would 
nevertheless also depend on the composition of the microbiome and the presence of "responsive" strains within the community.

Fourth, the stimulation of plant defense responses by individual BCA strains through induced systemic resistance (ISR) is a well-known phenomenon and one of the modes of action of BCAs. The interplay between these BCA strains and the host plant has been thoroughly studied and reviewed in detail elsewhere (Pieterse et al., 2014; Zamioudis and Pieterse, 2012). By contrast, the interplay between plant defense responses and the microbiota has been scarcely studied. Preliminary work highlighted the influence of plant defense pathways, such as systemic acquired resistance (SAR) and ISR, on the plant microbiota (Doornbos et al., 2012; Kniskern et al., 2007). Therefore the techniques used to study the effect of beneficial microbes on ISR could be adapted and combined with NGS to study the effect of the microbiota on ISR.

Fifth, the impact of BCAs on the plant microbiota has already been studied through classical and NGS approaches. Nevertheless, there is an emerging field of research that has often been suggested, but never addressed, i.e. the influence of the microbiota on BCA establishment and development. Antagonistic, commensal or mutualistic interactions between the microbiota and BCAs will influence pathogen control and pathogenesis. Microbiota strains, genes or pathways linked to improved or decreased BCA efficacy might be identified and used to promote BCA efficacy. This area could be an important field in biocontrol research in the future and has already been investigated into on animal models. The structure of a mouse gut microbiome can determine a positive or negative response to probiotics ingestion. This evidences the need to understand microbial community structure and function to appreciate and understand the full potential of these treatments (Veiga et al., 2010).

\section{Challenges for biocontrol research in the microbiome era}

Despite their potential, NGS approaches still present five important limitations likely to slow down their application in the study of plant microbiomes. These hurdles will have to be overcome for NGS to be fully reliable.

The origins of technical errors are detailed in (Knief, 2014). Briefly, sequencing accuracy ranges between 99.0 and $99.6 \%$ depending on the platform, with unequal distribution among the generated sequences. Ion Torrent (Life Technologies) and 454 (Roche) tend to create insertions and deletions in homopolymers, while Hiseq and Miseq machines (Illumina) tend to generate substitution errors mainly at the end of the reads in a sequence- and strand-dependent manner. The PCR steps prior to sequencing generate duplicated reads that need to be eliminated. Genome coverage is also unequal whatever the technology: some regions are well covered by sequencers, while others remain poorly sequenced. Some of these limitations, like accuracy and duplicated reads, are currently being progressively overcome. NGS technologies are continuously evolving, with simplifications in library preparation, suppression of prior PCR amplification, and chemistry improvements (Massart et al., 2014).

Data analysis is becoming the most crucial step in NGS approaches: it does not matter how much data you have if you cannot make sense out of it. Importantly, bioinformatics analysis of high-throughput sequencing data is in a transitional period. Initially largely cost-prohibitive and accessible only to bioinformaticians, NGS is becoming more and more cost-effective and user-friendly, in particular with the development of open commercial package platforms such as CLC Bio, Geneious or Galaxy (http://galaxyproject.org/) or of integrated metagenomics analysis packages like MG-RAST (Meyer et al., 2008). This transition also benefits directly from the exponential growth and cost reduction of computational power and from the availability of cloud computing. The current general trend is also to simplify the use and the parameterization of these tools, making them usable without extended bioinformatics skills. These efforts improve and facilitate the handling and analysis of the generated sequences and will favor the use of NGS in biocontrol research in the near future, for example to study the interaction between BCAs and resident microbial populations. Nevertheless, NGS still requires specific knowledge and skills to harvest useful information and to avoid generating biases in the analysis. Such biases can be introduced at any step of the process: experimental design and sample preparation (see next paragraph) as well as bioinformatics analysis. Each of the bioinformatics process (quality control, de novo contig assembly, contig annotation, sequence mapping on contigs, statistical comparison between samples) can generate biases, and there is currently no ideal protocol. Stringent protocols will discard many useful items of information, while relaxing the parameters will identify more false positive results. Results are not clear cut, and the information extracted from the data needs to be carefully analyzed and confirmed taking into account the parameters. Biocontrol researchers, including PhD or Master's students, would therefore need specific training in NGS data generation, handling and statistical analysis before analyzing microbiomes. Moreover, setting up a close collaboration with bioinformatics teams can also be recommended.

The high resolution of NGS approaches also requires the adaptation of experimental schemes. The first exploratory phase consists in generating NGS data from an experimental model. Then data analysis allows for the generation of new hypotheses, and these hypotheses must further be confirmed through complementary experiments using either classical methodologies, e.g. microbiology, biochemistry, microscopy, gene transformation and expression, or a new NGS approach. Finally, new scientific knowledge will be generated that will allow for a better understanding of microbiota functioning in pathogen and/or BCA development, and its effects on host physiology. The experimental model needs to be contrasted but well controlled: the generation of substantial amounts of data will increase the probability of finding statistical differences only by chance and due to confounding factors. Many statistical models have been developed for the analysis of microbiome data (Buttigieg and Ramette, 2014; Chaston et al., 2014; McMurdie and Holmes, 2013; Shakya et al., 2013; Xia et al., 2013). The most stringent analysis, including a Bonferroni correction (De Filippo et al., 2010), is not always applied, and there is no standardized statistical analysis yet. Once again, results cannot be $100 \%$ accurate, as a stringent model will not detect existing differences while a more relaxed model will generate false positives. Interesting models could compare the presence or absence of a BCA or/and a pathogen at a single or several growth and physiological stages of the plant. Sampling time is also a determining criterion. Most studies include a longitudinal comparison of the microbiome with time. Sampling should also go with a complete description of the physiological and symptomatic state of the plant. Moreover, a higher number of replicates would be recommended to minimize false positive results identified by chance within the huge amount of data. Samples should also be handled and processed very carefully, as NGS technologies are very sensitive to contamination. Sample contamination in fact frequently occurs but is seldom reported in many if not all laboratories using NGS approaches. In many cases, these problems are limited to a low proportion of reads and are of little consequence. For microbiome sequencing, such an impact can be higher as small contamination events can be mistaken for microbial strains present at very low abundance levels and represented by a few sequencing reads. 


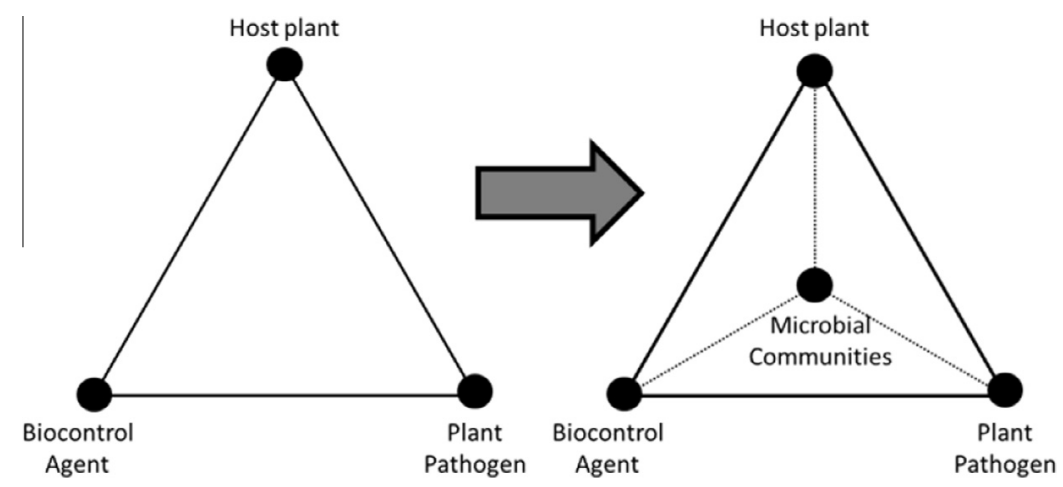

Fig. 3. Evolution of biocontrol research toward the integration of microbial communities into the current research triangle.

Importantly, NGS approaches using amplicon sequencing and metagenome sequencing only provide a relative quantification of the analyzed features. In some cases, it might be important to quantify the microbial population in terms of cells per square centimeter of leaves or gram of rhizosphere. Absolute quantification of the microbial population, whether bacterial or fungal, can be achieved by targeted real-time PCR. This absolute quantification can complete the relative quantification data from NGS approaches.

Metatranscriptomics is particularly interesting because it can differentiate between living and dead bacteria, and analyzes the microbial community at the true functional level. Nevertheless, several aspects about the methodological steps before RNA extraction and purification should be reconsidered to ensure a truly realistic representation of the genes expressed under a certain condition. For example, the protocol used to wash the rhizosphere and phyllosphere microbiota from the plant should be modified to reduce washing time. Most protocols currently rely on washing steps of 15 min up to more than one hour, but this is not always necessary. This sampling procedure can significantly modify microbiota gene expression and bias the analysis, as observed in deep sea water metatranscriptomics studies (Feike et al., 2012).

Genetic and genomic sequences of plant microbial communities are still lacking in databases, even though the gene families currently considered as important for biocontrol properties or plant-pathogen interactions are well characterized. The function of a generated sequence is most often inferred by homology with databases like Refseq or Swissprot, so the number of uncharacterized sequences or hypothetical proteins in a metagenome dataset can be high, up to 50\% (Kröber et al., 2014; Massart et al., unpublished results). Nevertheless, the number of available genomes from pathogens, BCAs or epiphytic strains is rapidly growing. Together with metagenomics data, this will build gene and genome catalogs of rhizosphere and phyllosphere microorganisms and facilitate data interpretation in the future. But beyond the increasing number of available genes and genomes, establishing a core microbiome for each crop species at the taxonomic or functional level remains an important question as yet to be addressed.

To shed light on this question, metagenomics studies of microbiota associated to each crop from different geographical origins and at different physiological states are essential, as already done in humans (Yatsunenko et al., 2012). A reference human gut metagenome was established by high-throughput sequencing (Qin et al., 2010), and comparative metagenomics between healthy controls and patients suffering from several disorders contributed to the characterization of a "healthy microbiome" (Greenblum et al., 2011; Qin et al., 2010; Tong et al., 2013). Interventional studies are also useful in defining a "healthy" microbiota, since changes in the microbial community induced by prebiotics, dietary interventions or pathogen infection can be studied in relation to clinical improvement or worsening. Thus, the genes and pathways associated with good health or disease can be identified (Chassaing et al., 2013; Everard et al., 2014). Therefore, defining the core microbiome of an environment as well as gene functionalities will be a cornerstone to predict situations that can drive to pathogen or BCA development or modify host physiology. This will be a tricky task, and underlines the importance of selecting appropriate pathosystems that are reasonably stable to start with, like greenhouse cultivation, controlled hydroponics or post-harvest storage.

\section{Conclusion}

The advent of NGS has brought about new opportunities to biocontrol research by integrating the study of microbial communities at the taxonomical and functional levels. Importantly, classical and NGS technologies should not be seen as competitors but as complementary, and their appropriate combination will facilitate the discovery of previously unknown or unexpected traits for plant pathogen control or BCA survival among community members.

We can expect a paradigm switch in the near future, from the classical biocontrol triangle (plant-pathogen-BCA) to the biocontrol prism that integrates the role of resident microbial communities (Fig. 3). This will be a complicated task because the composition and dynamics of a microbial community depend on multiple factors (ecological niche of the microorganisms, past and current environmental conditions, plant species and physiological state...) that will also influence on the survival and development of a foreign BCA within this community.

Initial hypotheses and experimental design are the key success factors of any microbiome analysis. Many studies are focused on generating sequences to simply answer the question "what is there?". This descriptive approach may have a limited impact for biocontrol and often raises a well-known comment: "So what?". For biocontrol research, microbiome studies should be considered as a tool to answer biocontrol-related questions (see examples in the text above), but not as the main question to be addressed. Moreover, designing an appropriate experimental model to address relevant hypotheses is a transdisciplinary task requiring the integration of expertise in biological control, microbiology, ecology, molecular biology and bioinformatics.

Altogether, these scientific discoveries will allow scientists to identify new ways of improving pathogen control by better timing application, or improving BCA formulation, or identifying helper microbial strains for the BCA, or developing molecules influencing on microbiota composition to promote "BCA-friendly" or "patho gen-antagonistic" microbiota.

\section{Conflict of interest}

The authors declare no conflict of interest for this publication. 


\section{References}

Adesina, M.F., Grosch, R., Lembke, A., Vatchev, T.D., Smalla, K., 2009. In vitro antagonists of Rhizoctonia solani tested on lettuce: rhizosphere competence, biocontrol efficiency and rhizosphere microbial community response. FEMS Microbiol. Ecol. 69, 62-74.

Arumugam, M., Raes, J., Pelletier, E., Le Paslier, D., Yamada, T., Mende, D.R., Fernandes, G.R., Tap, J., Bruls, T., Batto, J.-M., Bertalan, M., Borruel, N., Casellas, F., Fernandez, L., Gautier, L., Hansen, T., Hattori, M., Hayashi, T., Kleerebezem, M., Kurokawa, K., Leclerc, M., Levenez, F., Manichanh, C., Nielsen, H.B., Nielsen, T., Pons, N., Poulain, J., Qin, J., Sicheritz-Ponten, T., Tims, S., Torrents, D., Ugarte, E., Zoetendal, E.G., Wang, J., Guarner, F., Pedersen, O., de Vos, W.M., Brunak, S., Dore, J., Weissenbach, J., Ehrlich, S.D., Bork, P., 2011. Enterotypes of the human gut microbiome. Nature 473, 174-180.

Benítez, M.S., McSpadden Gardener, B.B., 2009. Linking sequence to function in soil bacteria: sequence-directed isolation of novel bacteria contributing to soilborne plant disease suppression. Appl. Environ. Microbiol. 75, 915-924.

Berg, G., Smalla, K., 2009. Plant species and soil type cooperatively shape the structure and function of microbial communities in the rhizosphere. FEMS Microbiol. Ecol. 68, 1-13.

Berg, G., Zachow, C., Müller, H., Philipps, J., Tilcher, R., 2013. Next-generation bioproducts sowing the seeds of success for sustainable agriculture. Agronomy 3, 8.

Berlec, A., 2012. Novel techniques and findings in the study of plant microbiota: search for plant probiotics. Plant Sci. 193-194, 96-102.

Bodenhausen, N., Bortfeld-Miller, M., Ackermann, M., Vorholt, J.A., 2014. A synthetic community approach reveals plant genotypes affecting the phyllosphere microbiota. PLoS Genet. 10.

Bragina, A., Oberauner-Wappis, L., Zachow, C., Halwachs, B., Thallinger, G.G., Müller, H., Berg, G., 2014. The Sphagnum microbiome supports bog ecosystem functioning under extreme conditions. Mol. Ecol. 23, 4498-4510.

Buddrus-Schiemann, K., Schmid, M., Schreiner, K., Welzl, G., Hartmann, A., 2010. Root colonization by Pseudomonas sp. DSMZ 13134 and impact on the indigenous rhizosphere bacterial community of barley. Microb. Ecol. 60, 381393.

Bulgarelli, D., Schlaeppi, K., Spaepen, S., Van Themaat, E.V.L., Schulze-Lefert, P., 2013. Structure and functions of the bacterial microbiota of plants. Ann. Rev. Plant Biol. 64, 807-838.

Buttigieg, P.L., Ramette, A., 2014. A guide to statistical analysis in microbial ecology: a community-focused, living review of multivariate data analyses. FEMS Microbiol. Ecol. 90, 543-550.

Cardinale, M., Grube, M., Erlacher, A., Quehenberger, J., Berg, G., 2015. Bacterial networks and co-occurrence relationships in the lettuce root microbiota. Environ. Microbiol.

Chassaing, B., Koren, O., Carvalho, F.A., Ley, R.E., Gewirtz, A.T., 2013. AIEC pathobiont instigates chronic colitis in susceptible hosts by altering microbiota composition. Gut 29, 2013-304909.

Chaston, J.M., Newell, P.D., Douglas, A.E., 2014. Metagenome-wide association of microbial determinants of host phenotype in drosophila melanogaster. mBio 5 , 15.

Chen, F., Wang, M., Zheng, Y., Li, S., Wang, H., Han, D., Guo, S., 2013. The effect of biocontrol bacteria on rhizosphere bacterial communities analyzed by plating and pcr-dgge. Curr. Microbiol. 67, 177-182.

Chowdhury, S.P., Dietel, K., Rändler, M., Schmid, M., Junge, H., Borriss, R., Hartmann, A., Grosch, R., 2013. Effects of Bacillus amyloliquefaciens FZB42 on lettuce growth and health under pathogen pressure and its impact on the rhizosphere bacterial community. PLoS One 8, e68818.

de Bruijn, F., 2013. Molecular Microbial Ecology of the Rhizosphere. WileyBlackwell.

De Filippo, C., Cavalieri, D., Di Paola, M., Ramazzotti, M., Poullet, J.B., Massart, S., Collini, S., Pieraccini, G., Lionetti, P., 2010. Impact of diet in shaping gut microbiota revealed by a comparative study in children from Europe and rural Africa. Proc. Natl. Acad. Sci. 107, 14691-14696.

Degrune, F., Dufrêne, M., Colinet, G., Massart, S., Taminiau, B., Bodson, B., Hiel, M.-P., Daube, G., Nezer, C., Vandenbol, M., 2015. A novel sub-phylum method discriminates better the impact of crop management on soil microbial community. Agron. Sustainable Dev. http://dx.doi.org/10.1007/s13593-0150291-4.

Dini-Andreote, F., van Elsas, J.D., 2013. Back to the basics: the need for ecophysiological insights to enhance our understanding of microbial behaviour in the rhizosphere. Plant Soil 373, 1-15.

Doornbos, R.F., Van Loon, L.C., Bakker, P.A.H.M., 2012. Impact of root exudates and plant defense signaling on bacterial communities in the rhizosphere, A review. Agron. Sustainable Dev. 32, 227-243.

Erlacher, A., Cardinale, M., Grosch, R., Grube, M., Berg, G., 2014. The impact of the pathogen Rhizoctonia solani and its beneficial counterpart Bacillus amyloliquefaciens on the indigenous lettuce microbiome. Front. Microbiol. 5, 1-5.

Everard, A., Lazarevic, V., Gaia, N., Johansson, M., Stahlman, M., Backhed, F., Delzenne, N.M., Schrenzel, J., Francois, P., Cani, P.D., 2014. Microbiome of prebiotic-treated mice reveals novel targets involved in host response during obesity. ISME J. 1, 1-5.

Feike, J., Jurgens, K., Hollibaugh, J.T., Kruger, S., Jost, G., Labrenz, M., 2012. Measuring unbiased metatranscriptomics in suboxic waters of the central Baltic Sea using a new in situ fixation system. ISME J. 6, 461-470.

Franzosa, E.A., Morgan, X.C., Segata, N., Waldron, L., Reyes, J., Earl, A.M., Giannoukos, G., Boylan, M.R., Ciulla, D., Gevers, D., Izard, J., Garrett, W.S., Chan, A.T.,
Huttenhower, . Relating the metatranscriptome and metagenome of the human gut. Proc. Natl. Acad. Sci. U.S.A. 111, 19.

Gopal, M., Gupta, A., Thomas, G.V., 2013. Bespoke microbiome therapy to manage plant diseases. Front. Microbiol. 4, 1-5.

Greenblum, S., Turnbaugh, P.J., Borenstein, E., 2011. Metagenomic systems biology of the human gut microbiome reveals topological shifts associated with obesity and inflammatory bowel disease. Proc. Natl. Acad. Sci. 1, 1-5.

Grosch, R., Scherwinski, K., Lottmann, J., Berg, G., 2006. Fungal antagonists of the plant pathogen Rhizoctonia solani: selection, control efficacy and influence on the indigenous microbial community. Mycol. Res. 110, 1464-1474.

Grosch, R., Dealtry, S., Schreiter, S., Berg, G., Mendonça-Hagler, L., Smalla, K., 2012. Biocontrol of Rhizoctonia solani: complex interaction of biocontrol strains, pathogen and indigenous microbial community in the rhizosphere of lettuce shown by molecular methods. Plant Soil 361, 343-357.

Hilton, S., Bennett, A.J., Keane, G., Bending, G.D., Chandler, D., Stobart, R., Mills, P., 2013. Impact of shortened crop rotation of oilseed rape on soil and rhizosphere microbial diversity in relation to yield decline. PLoS One 8, 1-5.

Ikeda, S., Anda, M., Inaba, S., Eda, S., Sato, S., Sasaki, K., Tabata, S., Mitsui, H., Sato, T., Shinano, T. Minamisawa, K., 2011. Autoregulation of nodulation interferes with impacts of nitrogen fertilization levels on the leaf-associated bacterial community in soybeans. Appl. Environ. Microbiol. 77, 1973-1980.

Inceoğlu, O., Al-Soud, W.A., Salles, J.F., Semenov, A.V., van Elsas, J.D., 2011. Comparative analysis of bacterial communities in a potato field as determined by pyrosequencing. PLoS One 6.

Jacobsen, C.S., Hjelmsø, M.H., 2014. Agricultural soils, pesticides and microbial diversity. Curr. Opin. Biotechnol. 27, 15-20.

Kim, Y.C., Leveau, J., McSpadden Gardener, B.B., Pierson, E.A., Pierson, L.S., Ryu, C.M., 2011. The multifactorial basis for plant health promotion by plant-associated bacteria. Appl. Environ. Microbiol. 77, 1548-1555.

Klein, E., Ofek, M., Katan, J., Minz, D., Gamliel, A., 2012. Soil suppressiveness to fusarium disease: shifts in root microbiome associated with reduction of pathogen root colonization. Phytopathology 103, 23-33.

Knief, C., 2014. Analysis of plant-microbe interactions in the era of next generation sequencing technologies. Front. Plant Sci. 5.

Kniskern, J.M., Traw, M.B., Bergelson, J., 2007. Salicylic acid and jasmonic acid signaling defense pathways reduce natural bacterial diversity on Arabidopsis thaliana. Mol. Plant Microbe Interact. 20, 1512-1522.

Kröber, M.S., Wibberg, D., Grosch, R., Eikmeyer, F.G., Verwaijen, B., Chowdhury, S.P., Hartmann, A., Pühler, A., Schlüter, A., 2014. Effect of the biocontrol strain Bacillus amyloliquefaciens FZB42 on the microbial community in the rhizosphere of lettuce under field conditions analyzed by whole metagenome sequencing. Front. Microbiol. 5.

Lindow, S.E., Brandl, M.T., 2003. Microbiology of the phyllosphere. Appl. Environ. Microbiol. 69, 1875-1883.

Martins, G., Lauga, B., Miot-Sertier, C., Mercier, A., Lonvaud, A., Soulas, M.-L., Soulas, G., Masneuf-Pomarède, I., 2013. Characterization of epiphytic bacterial communities from grapes, leaves, bark and soil of grapevine plants grown, and their relations. PLoS One 8, e73013.

Massart, S., Olmos, A., Jijakli, H., Candresse, T., 2014. Current impact and future directions of high throughput sequencing in plant virus diagnostics. Virus Res. 188, 90-96.

McMurdie, P.J., Holmes, S., 2013. Phyloseq: an R package for reproducible interactive analysis and graphics of microbiome census data. PLoS One 8.

Meyer, F., Paarmann, D., D’Souza, M., Olson, R., Glass, E.M., Kubal, M., Paczian, T. Rodriguez, A., Stevens, R., Wilke, A., Wilkening, J., Edwards, R.A., 2008. The metagenomics RAST server - a public resource for the automatic phylogenetic and functional analysis of metagenomes. BMC Bioinformatics 9.

Moulas, C., Petsoulas, C., Rousidou, K., Perruchon, C., Karas, P., Karpouzas, D.G., 2013. Effects of systemic pesticides imidacloprid and metalaxyl on the phyllosphere of pepper plants. BioMed. Res. Int. 2013.

Nelson, A.M., Walk, S.T., Taube, S., Taniuchi, M., Houpt, E.R., Wobus, C.E., Young, V.B., 2012. Disruption of the human gut microbiota following norovirus infection. PLoS One 7, e48224.

Perazzolli, M., Antonielli, L., Storari, M., Puopolo, G., Pancher, M., Giovannini, O., Pindo, M., Pertot, I., 2014. Resilience of the natural phyllosphere microbiota of the grapevine to chemical and biological pesticides. Appl. Environ. Microbiol. 80, 3585-3596.

Pieterse, C.M.J., Zamioudis, C., Berendsen, R.L., Weller, D.M., Van Wees, S.C.M., Bakker, P.A.H.M., 2014. Induced systemic resistance by beneficial microbes. Annu. Rev. Phytopathol., 347-375

Qin, J., Li, R., Raes, J., Arumugam, M., Burgdorf, K.S., Manichanh, C., Nielsen, T., Pons, N., Levenez, F., Yamada, T., Mende, D.R., Li, J., Xu, J., Li, S., Li, D., Cao, J., Wang, B., Liang, H., Zheng, H., Xie, Y., Tap, J., Lepage, P., Bertalan, M., Batto, J.M., Hansen, T., Le Paslier, D., Linneberg, A., Nielsen, H.B., Pelletier, E., Renault, P., Sicheritz-Ponten, T., Turner, K., Zhu, H., Yu, C., Jian, M., Zhou, Y., Li, Y., Zhang, X., Qin, N., Yang, H., Wang, J., Brunak, S., Dore, J., Guarner, F., Kristiansen, K., Pedersen, O., Parkhill, J., Weissenbach, J., Bork, P., Ehrlich, S.D., 2010. A human gut microbial gene catalogue established by metagenomic sequencing. Nature 464, 59-65.

Rastogi, G., Sbodio, A., Tech, J.J., Suslow, T.V., Coaker, G.L., Leveau, J.H., 2012. Leaf microbiota in an agroecosystem: spatiotemporal variation in bacterial community composition on field-grown lettuce. ISME J. 6, 1812-1822.

Rastogi, G., Coaker, G.L., Leveau, J.H.J., 2013. New insights into the structure and function of phyllosphere microbiota through high-throughput molecular approaches. FEMS Microbiol. Lett. 348, 1-10. 
108

S. Massart et al./Biological Control 89 (2015) 98-108

Redford, A.J., Bowers, R.M., Knight, R., Linhart, Y., Fierer, N., 2010. The ecology of the phyllosphere: geographic and phylogenetic variability in the distribution of bacteria on tree leaves. Environ. Microbiol. 12, 2885-2893.

Sang, M.K., Kim, K.D., 2012. Plant growth-promoting rhizobacteria suppressive to Phytophthora blight affect microbial activities and communities in the rhizosphere of pepper (Capsicum annuum L.) in the field. Appl. Soil Ecol. 62, 88-97.

Scherwinski, K., Wolf, A., Berg, G., 2007. Assessing the risk of biological control agents on the indigenous microbial communities: Serratia plymuthica HRO-C48 and Streptomyces sp. HRO-71 as model bacteria. Biocontrol 52, 87-112.

Schmidt, R., Koberl, M., Mostafa, A., Ramadan, E.M., Monschein, M., Jensen, K.B., Bauer, R., Berg, G., 2014a. Effects of bacterial inoculants on the indigenous microbiome and secondary metabolites of chamomile plants. Front. Microbiol. 5,64 .

Schmidt, R., Köberl, M., Mostafa, A., Ramadan, E.M., Monschein, M., Jensen, K.B., Bauer, R., Berg, G., 2014b. Effects of bacterial inoculants on the indigenous microbiome and secondary metabolites of chamomile plants. Front. Microbiol. 5.

Schreiter, S., Ding, G.C., Grosch, R., Kropf, S., Antweiler, K., Smalla, K., 2014a. Soil type-dependent effects of a potential biocontrol inoculant on indigenous bacterial communities in the rhizosphere of field-grown lettuce. FEMS Microbiol. Ecol.

Schreiter, S., Sandmann, M., Smalla, K., Grosch, R., 2014b. Soil type dependent rhizosphere competence and biocontrol of two bacterial inoculant strains and their effects on the rhizosphere microbial community of field-grown lettuce. PLoS One 9, e103726.

Shakya, M., Gottel, N., Castro, H., Yang, Z.K., Gunter, L., Labbé, J., Muchero, W., Bonito, G., Vilgalys, R., Tuskan, G., Podar, M., Schadt, C.W., 2013. A multifactor analysis of fungal and bacterial community structure in the root microbiome of mature Populus deltoides trees. PLoS One 8.

Smalla, K., Wieland, G., Buchner, A., Zock, A., Parzy, J., Kaiser, S., Roskot, N., Heuer, H., Berg, G., 2001. Bulk and rhizosphere soil bacterial communities studied by denaturing gradient gel electrophoresis: plant-dependent enrichment and seasonal shifts revealed. Appl. Environ. Microbiol. 67, 4742-4751.

Sylla, J., Alsanius, B.W., Krüger, E., Reineke, A., Strohmeier, S., Wohanka, W., 2013. Leaf microbiota of strawberries as affected by biological control agents. Phytopathology 103, 1001-1011.

Teixidó, N., Usall, J., Gutierrez, O., Viñas, I., 1998. Effect of the antagonist Candida sake on apple surface microflora during cold and ambient (shelf life) storage. Eur. J. Plant Pathol. 104, 387-398.
Tong, M., Li, X., Wegener Parfrey, L., Roth, B., Ippoliti, A., Wei, B., Borneman, J., McGovern, D.P.B., Frank, D.N., Li, E., Horvath, S., Knight, R., Braun, J., 2013. A modular organization of the human intestinal mucosal microbiota and its association with inflammatory bowel disease. PLoS One 8, e80702.

Vayssier-Taussat, M., Albina, E., Citti, C., Cosson, J.F., Jacques, M.A., Lebrun, M.H., Le Loir, Y., Ogliastro, M., Petit, M.A., Roumagnac, P., Candresse, T., 2014. Shifting the paradigm from pathogens to pathobiome new concepts in the light of metaomics. Front. Cell. Infect. Microbiol. 5.

Veiga, P., Gallini, C.A., Beal, C., Michaud, M., Delaney, M.L., DuBois, A., Khlebnikov, A., van Hylckama Vlieg, J.E.T., Punit, S., Glickman, J.N., Onderdonk, A., Glimcher, L.H., Garrett, W.S., 2010. Bifidobacterium animalis subsp. lactis fermented milk product reduces inflammation by altering a niche for colitogenic microbes. Proc. Natl. Acad. Sci. 1, 1.

Vorholt, J.A., 2012. Microbial life in the phyllosphere. Nat. Rev. Microbiol. 10, 828-840. Walter, M., Frampton, C.M., Boyd-Wilson, K.S.H., Harris-Virgin, P., Waipara, N.W., 2007. Agrichemical impact on growth and survival of non-target apple phyllosphere microorganisms. Can. J. Microbiol. 53, 45-55.

Whitman, W.B., Coleman, D.C., Wiebe, W.J., 1998. Prokaryotes: the unseen majority. Proc. Natl. Acad. Sci. 95, 6578-6583.

Xia, F., Chen, J., Fung, W.K., Li, H., 2013. A logistic normal multinomial regression model for microbiome compositional data analysis. Biometrics 69, 1053-1063.

Yatsunenko, T., Rey, F.E., Manary, M.J., Trehan, I., Dominguez-Bello, M.G., Contreras, M., Magris, M., Hidalgo, G., Baldassano, R.N., Anokhin, A.P., Heath, A.C., Warner, B., Reeder, J., Kuczynski, J., Caporaso, J.G., Lozupone, C.A., Lauber, C., Clemente, J.C., Knights, D., Knight, R., Gordon, J.I., 2012. Human gut microbiome viewed across age and geography. Nature 486, 222-227.

Yin, D., Wang, N., Xia, F., Li, Q., Wang, W., 2013. Impact of biocontrol agents Pseudomonas fluorescens 2P24 and CPF10 on the bacterial community in the cucumber rhizosphere. Eur. J. Soil Biol. 59, 36-42.

Zamioudis, C., Pieterse, C.M.J., 2012. Modulation of host immunity by beneficial microbes. Mol. Plant Microbe Interact. 25, 139-150.

Zhang, B., Bai, Z., Hoefel, D., Tang, L., Yang, Z., Zhuang, G., Yang, J., Zhang, H., 2008. Assessing the impact of the biological control agent Bacillus thuringiensis on the indigenous microbial community within the pepper plant phyllosphere. FEMS Microbiol. Lett. 284, 102-108.

Zhang, B., Bai, Z., Hoefel, D., Tang, L., Wang, X., Li, B., Li, Z., Zhuang, G., 2009. The impacts of cypermethrin pesticide application on the non-target microbial community of the pepper plant phyllosphere. Sci. Total Environ. 407, 19151922. 